Dhaka Univ. J. Biol. Sci. 20(2): 147-154, 2011 (July)

\title{
DIURNAL VERTICAL MIGRATION OF SOME CLADOCERANS IN RELATION TO THE PHYSICO-CHEMICAL FACTORS IN A FISH POND
}

\author{
A. S. BhuiYAN*, S. AKTHER AND M. M. A. Quddus ${ }^{1}$ \\ Department of Zoology, University of Rajshahi, Rajshahi-6205, Bangladesh
}

Key words: Cladocera, Diurnal migration, Physico-chemical parameters, Fish pond

\begin{abstract}
Diurnal vertical migration of four genera of cladocerans, namely Diaphanosoma sp., Daphnia sp., Moina sp. and Bosmina sp., during March to December, 2007 showed that the number of Diaphanosoma sp. was 501 units/1 in the surface layers, 172 units/l in the middle layers and 190 units/l in the bottom layers. The yearly number of Daphnia sp. in surface, middle and bottom layerss was 362 units/l, 46 units/l and 189 units/l respectively. In surface, bottom and middle layers, the number of Moina sp. was 159, 71 and 32 uiiits/l, respectively. Bosmina sp. was 78 units/l in surface, 31 units/l in the middle and 33 units/l in the bottom layers. The number of Diaphanosoma sp., Daphnia sp., Moina sp., Bosmina sp., were 455, 149, 259 and 358 units/l, respectively in the morning, 63, 176, 142, 43 units/l at noon and 107, 55, 28, 59 units/l, respectively in the evening. Throughout the study period the cladocerans were always abundant near the surface during morning and evening. Among the factors responsible for the diurnal movement of cadoceran, light played the most important factor. The relationship between the physico-chemical factors and the cladoceran occurrence in the pond was also explored.
\end{abstract}

\section{Introduction}

Plankton is the major nutritional source available from nature which is the measure of the degree of organic enrichment of water. A pond with good water quality will produce more healthy fish than a pond with poor water quality. So, the production of fish in any water body depends largely on the availability of food organisms. Plankton plays the major role as fish food because freshwater fishes are chiefly plankton feeders. Zooplankton is the link in the food chain between the primary producers and the necktonic as well as benthic animals in higher tropic levels. The role of plankton has a direct effect on the well being of fishes. The change of food organisms of fishes throughout the year is primarily due to the change in the composition of food organism at different seasons. ${ }^{(1,2)}$ It is well-known that zooplankton exhibits diurnal and vertical movements in response to light. The cause of their movement in different layers at different time of the day are rather difficult to determine as there may be multiplicity of

${ }^{*}$ Corresponding author. ${ }^{1}$ Department of Zoology, University of Dhaka, Dhaka-1000, Bangladesh. 
factors. There are numerous exceptions to any general rule regarding vertical distribution of zooplanktonic organisms. The zooplankters generally avoid strong light and recede to lower regions. Ganapati( ${ }^{(3)}$ investigated in detail the hydrobiology of three summer pools with particular reference to the diurnal variations in temperature and the dissolved oxygen content of biological significance. Cushing ${ }^{(4)}$ observed the vertical migration of planktonic crustaceans. Borecky(5) made a conclusion on the number of cladocerans depending upon the concentration of $\mathrm{pH}$, carbonate ions and bicarbonate ions which were closely related with photosynthetic activity. He recorded the greatest number of cladoceran in a lake during the highest photosynthetic rate. George ${ }^{(6)}$ investigated the diurnal changes in plankton during typical summer condition in shallow waters of North India. Krishnamoorthi and Vesweswara ${ }^{(7)}$ made a hydrobiological investigation of the Gandhisagar at Nagpur with diurnal variation in plankton ${ }^{(8)}$ observed the diurnal variation of plankton in the pond at Aligarh. Michael ${ }^{(9)}$ investigated the diurnal variation in physico-chemical factors and zooplankton on the surface layers of three freshwater ponds Saha et al.(10) studied the seasonal and diurnal variation in physico-chemical and biological conditions of a perennial freshwater pond in Bangladesh. Singh et al.(11) studied the seasonal and diurnal variations in terms of physico-chemical conditions of water and plankton in lentic water of Riha reservoir in India. Bhuiyan and Nessa ${ }^{(12,13)}$ and Bhuiyan et al.(14) studied the physico-chemical condition, occurrence and migration of some cladocerans in a pond of Rajshahi University campus in Bangladesh. They reported that cladocerans were the major group and they showed significant correlationship between the cladocerans and physico-chemical parameters. The present study deals with the diurnal vertical migration of cladocerans in relation to the physico-chemical factors in a fish pond in Rajshahi of Bangladesh.

\section{Materials and Methods}

The present investigation was conducted in a fish pond situated in the north side of Rajshahi University campus for a period of 10 months starting from March to December 2007. The pond covers an area of 3,096 $\mathrm{m}^{2}$ with an average depth of $3.8 \mathrm{~m}$. The water was clearly visible, no bloom seen and it received sunlight throughout the period of investigation.

Samples were collected at weekly interval in morning (06 h), noon (12 h) and evening $(18 \mathrm{~h})$ from surface, middle and bottom layerss of the pond. Physical parameter such as air and water temperature was measured using centigrade thermometer. Chemical factors such as $\mathrm{CO}_{2}$, dissolved oxygen (DO), carbonate and bicarbonate alkalinity were measured by titration method following the Winkler's method (APHA 1976) and also by a water quality checker (20 A, TOA-Japan). $\mathrm{pH}$ was measured by a digital $\mathrm{pH}$ meter ( $\mathrm{pH}$ Tester $^{2 \mathrm{TM}}$ ) made in Singapore. Plankton was collected by a plankton net of No. 20 count bolting cloth and the specimens were preserved in Transeau's solution. The cladocerans 
were identified.(15-18) The numerical assessment of cladocerans was done by SedgewickRafter counting cell.

\section{Results and Discussion}

Some selected physico-chemical factors of the water of the pond were studied (Figs 1-2).

Air temperature varied from $36.1^{\circ} \mathrm{C}$ (May) to $11.5^{\circ} \mathrm{C}$ (December). Yearly mean of air temperature was found as $27.24^{\circ} \mathrm{C} \pm 3.85$.

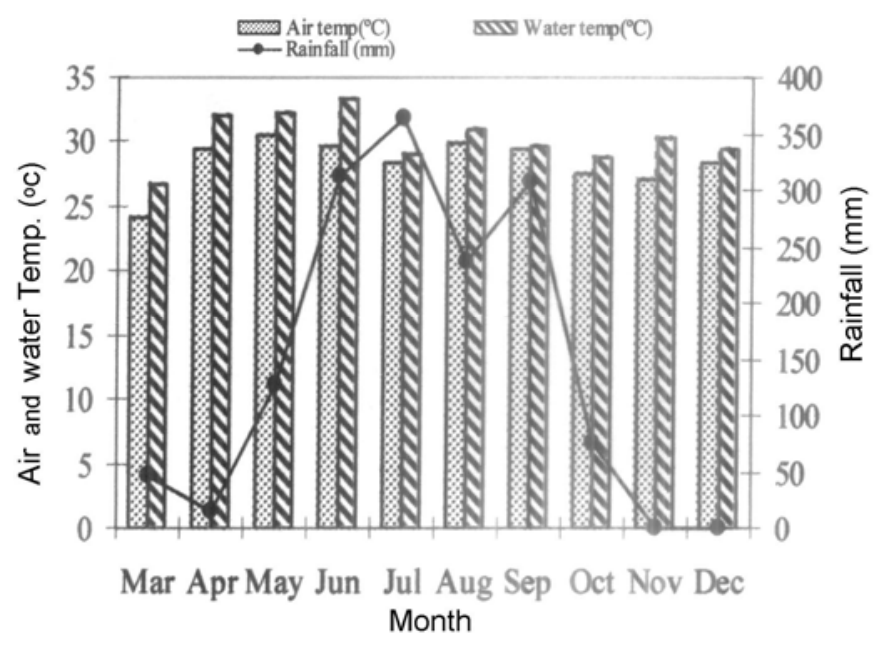

Fig. 1. Monthly fluctuation of physical parameters of the study pond in 2007.

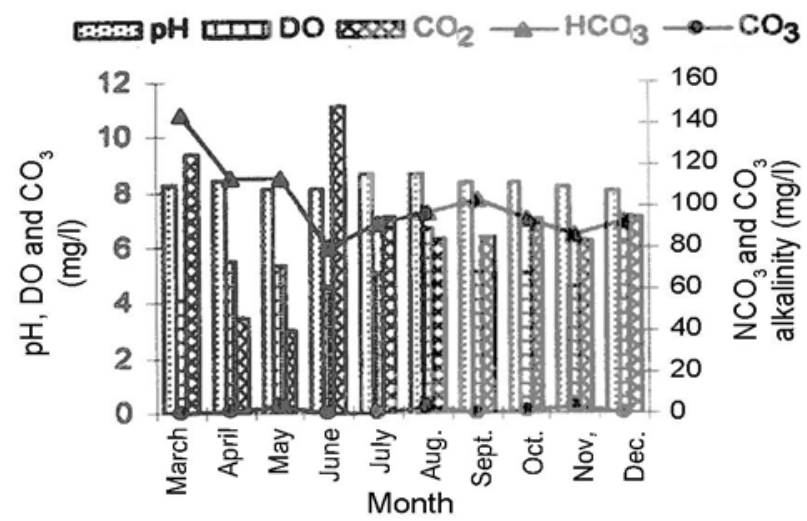

Fig. 2. Monthly fluctuation of chemical parameters of the study pond in 2007.

Water temperature varied from $36^{\circ} \mathrm{C}$ (June) to $17.01^{\circ} \mathrm{C}$ (December). The highest morning, noon and evening mean water temperature was recorded as $31.54,34.68$ and $32.85^{\circ} \mathrm{C}$. in the month of June and the lowest mean value of water temperature at 
morning, noon and evening was recorded as $18.00,19.55$ and $17.79^{\circ} \mathrm{C}$, respectively in the month of December. Yearly mean of water temperature was found as $28.32 \mathrm{mg} / 1 \pm 4.64$.

The pond water showed somewhat alkaline in nature with small variation. The $\mathrm{pH}$ was noted to fluctuate between 7.5 (May) and 9.5 (July). The highest mean value of $\mathrm{pH}$ in morning, noon and evening were recorded as 8.53 (August), 8.72 (April) and 8.66 (August), respectively. The lowest mean value of $\mathrm{pH}$ in morning, noon and evening were recorded as 7.72 (May), 8.14 (November) and 8.13 (November) respectively. Yearly mean $p \mathrm{H}$ value of water was found as $8.33 \pm 0.21$.

The DO content of water varied from a minimum $2.00 \mathrm{mg} / \mathrm{l}$ (March) to a maximum $9.00 \mathrm{mg} / \mathrm{l}$ (December). The highest mean value of DO was $7.87 \mathrm{mg} / \mathrm{l}$ at surface (August), $.59 \mathrm{mg} / \mathrm{l}$ at middle (December) and $11.2 \mathrm{mg} / \mathrm{l}$ at bottom (August). The lowest mean value of DO were $4.3 \mathrm{mg} / \mathrm{l}$ at surface, $2.95 \mathrm{mg} / \mathrm{l}$ at middle, $4.63 \mathrm{mg} / \mathrm{l}$ at bottom in the month of March. Yearly mean DO value of water was found as $5.25(\mathrm{mg} / \mathrm{l}) \pm 0.79$.

The lowest free $\mathrm{CO}_{2}$ was recorded $0.0 \mathrm{mg} / \mathrm{l}$ (April, May, June, July, August and November) and the highest value was record $19.00 \mathrm{mg} / \mathrm{l}$ (June). The highest free $\mathrm{CO}_{2}$ mean value at surface, middle and bottom were $842,8.59$ and $11.2 \mathrm{mg} / \mathrm{l}$ in March and lowest were 1.42, 2.95 and $4.63 \mathrm{mg} / \mathrm{l}$, respectively in the month of May. Yearly mean $\mathrm{CO}_{2}$ value of water was found as $6.73(\mathrm{mg} / \mathrm{l}) \pm 2.41$.

The bicarbonate alkalinity varied between $69 \mathrm{mg} / \mathrm{l}$ (June) and $186 \mathrm{mg} / \mathrm{l}$ (March). The highest mean value of $\mathrm{HCO}_{3}$ alkalinity at surface, middle and bottom were recorded as 143.84, 145.84 and $141.84 \mathrm{mg} / \mathrm{l}$ in March and the lowest mean value were 84, 78.84, 78.84, respectively in June. Yearly mean HCO alkalinity value of water was found as 101.49 $\mathrm{mg} / \mathrm{l} \pm 18.51$.

The range of carbonate alkalinity was lowest $0.0 \mathrm{mg} / \mathrm{l}$ (March) and highest $12 \mathrm{mg} / \mathrm{l}$ (October). The highest mean value of $\mathrm{HCO}_{3}$ alkalinity at surface, middle and bottom were recorded as 4.71 and $3.99 \mathrm{mg} / \mathrm{l}$ in August and $1.95 \mathrm{mg} / \mathrm{l}$ in November and the lowest mean value were 0.0, 0.0, $0.0 \mathrm{mg} / \mathrm{l}$, respectively in March, June, July, September, October, December. Yearly mean of CO alkalinity value of water was found as $1.114 \mathrm{mg} / \mathrm{l} \pm 1.42$.

The total cladoceran number was always found abundant near the surface during the early morning and evening and in lesser number in the noon throughout the study period. This type of variation occurred due to differences in light intensity and temperature variation in the upper levels of water. In order to ensure better oxygen consumption, cladoceran migrated towards the surface layers. On the contrary, lower temperature as well as high availability of detritus and debris played significant role for high concentration of ciadoceran in the bottom layers at noon. This is in conformity with the findings of Beeton ${ }^{(19)}$, Micheal.(9) During the study period different cladocerans showed different vertical migrations.

Diaphanosoma sp. was abundant round the year during the study period and found in large numbers ii springs and less in number in summer season. The number increased 
near the surface and bottom layers in morning and evening and in the surface layers during noon. The yearly occurrence of Diaphanosoma sp. in surface, middle and bottom layers was 501, 172 and 190 units/l, respectively.

Daphnia sp. was more in surface layers and less in number in middle layers. The 2 of Daphnia sp. in surface, middle and bottom layers were 362, 46 and 189 units/l, respectively.

The number of Moina sp. was rich in surface layers whereas its presence in bottom layers was considerably lower than surface and middle layers throughout the year. The yearly occurrence of Moina sp. in surface, middle and bottom layers was 159, 71 and 62 units/l, respectively.

Bosmina sp. was abundant in December and less in number in March. It reached peak in number near the surface layers in morning and evening. The yearly occurrence of Bosmina sp. in surface, middle and bottom layers was 78, 31 and 33 units/l, respectively (Table 1).

Table 1. Depth wise monthly occurrence of cladoceran (units/l) of the study pond.

\begin{tabular}{lllllllllllll}
\hline Months & & Mar. & Apr. & May & June & July & Aug. & Sept. & Oct. & Nov. & Dec. & Total \\
\hline Diaphanosoma sp. & Sur. & 52 & 41 & 31 & 31 & 38 & 29 & 43 & 42 & 87 & 107 & 501 \\
& Mid. & 26 & 11 & 13 & 4 & 8 & 7 & 10 & 9 & 36 & 48 & 172 \\
\multirow{5}{*}{ Daphnia sp. } & Bot. & 26 & 16 & 17 & 8 & 15 & 12 & 19 & 18 & 25 & 34 & 190 \\
& Sur. & 31 & 26 & 22 & 10 & 17 & 19 & 33 & 46 & 69 & 89 & 362 \\
& Mid. & 7 & 6 & 0 & 0 & 0 & 0 & 0 & 0 & 0 & 33 & 46 \\
Moina sp. & Bot. & 16 & 15 & 8 & 3 & 10 & 12 & 20 & 32 & 36 & 37 & 189 \\
& Sur. & 33 & 16 & 14 & 3 & 0 & 0 & 0 & 0 & 0 & 80 & 159 \\
Bosmina sp. & Mid. & 17 & 2 & 2 & 0 & 0 & 0 & 0 & 0 & 0 & 46 & 71 \\
& Bot. & 14 & 6 & 4 & 1 & 0 & 0 & 0 & 0 & 0 & 5 & 32 \\
& Sur. & 30 & 0 & 0 & 0 & 0 & 0 & 0 & 0 & 0 & 48 & 78 \\
& Mid. & 11 & 0 & 0 & 0 & 0 & 0 & 0 & 0 & 0 & 20 & 31 \\
& Bot. & 10 & 0 & 0 & 0 & 0 & 0 & 0 & 0 & 0 & 23 & 33 \\
\hline
\end{tabular}

It was evident from the present study that most cladoceran species migrated upward from deeper waters to more sacrificial strata as darkness approaches and returned to deeper strata at noon. Maximum number of ciadoceran was found in surface layers in nocturnal migration in a single maximum some time between sunset and sunrise. In other cases, twilight migration resulted in two maxima in surface layers, one at dawn and another at dusk. The photic hour migration of some cladocerans was as follows.

From the yearly variation in different layers it was evident that Diaphanosoma sp. was 455 units/l in the morning, 149 units/l in noon and 259 units/l in evening.

Daphnia sp. was maximum in morning sampling 358 units/l, minimum in noon sampling 63 units/l and then started increasing 176 units/l in evening. 
Yearly abundance of Moina sp. was 142, 43 uand 107 units/l in morning, noon and evening respectively.

Yearly abundance of Moina sp. was 55 units/l in morning, 28 units/l in noon and 59 units/l in evening (Table 2).

Table 2. Monthly photic hour distribution of cladoceran (units/I) of the study pond.

\begin{tabular}{lllllllllllll}
\hline Months & & Mar. & Apr. & May & June & July & Aug. & Sept. & Oct. & Nov. & Dec. & Total \\
\hline Diaphanosoma sp. & Morn. & 55 & 35 & 23 & 20 & 39 & 27 & 43 & 42 & 78 & 93 & 455 \\
& Noon & 23 & 12 & 15 & 6 & 5 & 11 & 14 & 13 & 21 & 29 & 149 \\
& Even. & 26 & 21 & 23 & 17 & 17 & 10 & 15 & 14 & 49 & 67 & 259 \\
Daphnia sp. & Morn. & 22 & 24 & 8 & 10 & 18 & 20 & 37 & 54 & 78 & 87 & 358 \\
& Noon & 15 & 10 & 9 & 2 & 1 & 1 & 1 & 2 & 1 & 21 & 63 \\
Moina sp. & Even. & 17 & 13 & 13 & 1 & 8 & 10 & 15 & 22 & 26 & 51 & 176 \\
& Morn. & 26 & 12 & 16 & 4 & 0 & 0 & 0 & 0 & 10 & 74 & 142 \\
& Noon & 9 & 1 & 0 & 0 & 0 & 0 & 0 & 0 & 3 & 30 & 43 \\
Bosmina sp. & Even. & 29 & 11 & 4 & 0 & 0 & 0 & 0 & 0 & 9 & 54 & 107 \\
& Morn. & 26 & 0 & 0 & 0 & 0 & 0 & 0 & 0 & 0 & 29 & 55 \\
& Noon & 8 & 0 & 0 & 0 & 0 & 0 & 0 & 0 & 0 & 20 & 28 \\
& Even. & 17 & 0 & 0 & 0 & 0 & 0 & 0 & 0 & 0 & 42 & 59 \\
\hline
\end{tabular}

During the present investigation, the highest number of cladoceran was recorded in December 2007. In general the planktonic number decreases with the increase of temperature. Temperature influences both directly and indirectly of the vertical and photic hour migration. High temperature acted as an important barrier for the upward migration of cladocerans while certain other forms like Mycrocystis sp. was not influenced by the vertical temperature variation in photic hours. ${ }^{(20)}$

Cladocerans showed negative relationship with rainfall $(\mathrm{r}=-0.68)$, water temperature $(\mathrm{r}=-0.89), \mathrm{pH}(\mathrm{r}=-0.53), \mathrm{CO}_{3}$ alkalinity $(\mathrm{r}=-0.22)$ and positive relationship with $\mathrm{DO}$ $(\mathrm{r}=0.18)$, free $\mathrm{CO}_{2}(\mathrm{r}=0.02), \mathrm{HCO}_{3}$ alkalinity $(\mathrm{r}=0.08)$.

Diaphanosoma sp. showed a limited degree of positive relationship with DO $(\mathrm{r}=0.05)$, free $\mathrm{CO}_{2}(\mathrm{r}=0.02)$ and negative relationship with $\mathrm{pH}(\mathrm{r}=-0.52), \mathrm{CO}_{3}$ alkalinity $(\mathrm{r}=-0.11)$ and $\mathrm{HCO}_{3}$ alkalinity $(\mathrm{r}=-0.02)$, water temperature $(\mathrm{r}=-0.96)$. Daphnia sp. showed positive relationship with $\mathrm{DO}(\mathrm{r}=0.20)$ and inverse relationship with water temperature $(\mathrm{r}=-0.92), \mathrm{pH}(\mathrm{r}-0.46)$, free $\mathrm{CO}_{2}(\mathrm{r}=-0.57), \mathrm{CO}_{3}$ alkalinity $(\mathrm{r}=-0.10), \mathrm{HCO}_{3}$ alkalinity $(\mathrm{r}=$ $-0.14)$. Moina sp. showed highly negative relationship with DO $(\mathrm{r}=-0.23)$ and limited degree of positive relationship with free $\mathrm{CO}_{2}(\mathrm{r}=0.08), \mathrm{HCO}_{3}$ alkalinity $(\mathrm{r}=0.17)$ and negative relationship with water temperature $(\mathrm{r}=-0.77), \mathrm{pH}(\mathrm{r}=-0.56), \mathrm{CO}_{3}$ alkalinity $(\mathrm{r}$ $=-0.28)$. Bosmina sp. showed limited degree of positive relationship with DO $(r=0.16)$, free $\mathrm{CO}_{2}(\mathrm{r}=0.25)$ and $\mathrm{HCO}_{3}$ alkalinity $(\mathrm{r}=0.25)$. It showed negative relationship with water temperature $(\mathrm{r}=-0.75), \mathrm{CO}_{3}$ alkalinity $(\mathrm{r}=-0.39)$ and $\mathrm{pH}(\mathrm{r}=-0.46)$. The correlation 
co-efficient between different cladocerans and physico-chemical factors of water were calculated and shown.

From the present observation it is observed that the cladocerans were relatively abundant in bottom layers of water at morning and evening time. At noon, they were sometime absent at the surface layers and found at the bottom layers. So it can be concluded that light is the most important factor for the vertical migration of the cladocerans.

Miah and Dewan(21) also found that plankton is the important food of L. rohita. Bhuiyan et al.(22) found a positive co-relationship between the copepods distribution and the dissolved oxygen $(\mathrm{r}=0.48)$ and negative relationship with water temperature $(\mathrm{r}=-0.5),. \mathrm{pH}(\mathrm{r}=-0.16)$ and $\mathrm{CO}_{2}(\mathrm{r}=-0.40)$. They also found positive relationship between the cyclops and DO $(\mathrm{r}=0.22)$. Bhuiyan et al.(23) observed the occurrence and abundance of some copepods in a fish pond of Rajshahi. They also studied the diurnal migration of copepods.

\section{References}

1. Dewan S, M Au and MA Islam MA 1977. Study on the size patterns of feeding of fries and, fingerlings of three major major carps, rohita (Ham) Catla catla (Ham) and Cirrhina mrigal (Ham). Bangladesh J. Agril. 2(2): 223-228.

2. Ali MM and MA Islam 1983. Studies on the plankton of lake in Bangladesh Agricultural University Campus, Mymensing. Bangladesh J. Aqua. 2-5(1): 41-61.

3. Ganapati SV 1960. Ecology of tropical waters. Proc. Symp. On Algology 1959. Indian Couunc. Agric. Res. New Delhi. pp 204-218.

4. Cushing DH 1951. The vertical migration of planktonic crustacean. Biol. Rev. 26: 158-192.

5. Borecky GW 1956. Population density of the limnetic Cladocera of Pymatuning reservoir. Ecology 37: 719-27.

6. George MG 1961. Diurnal variation in two shallow ponds in Delhi, India, Hydrobiol. 27 (1\&2): 81-108.

7. Krishnarnoorthi KP and VG Vesweswara 1964. Hydrobiological studies in the Gandhisagar (Jumna tank). Diurnal variation in plankton (1961-62). Hydrobiol. 27: 99-118.

8. Khan AA and AQ Siddique 1970. Diurnal variations in the pon moat at Aligarh. J. Ind. fish. Soc. India 2: 146-154.

9. Michael RG 1970. Hydrobiology of the Pulicat lake. Adv. Abstr. Contr. Fish. Aqua. Sci. India $4(1): 49$.

10. Saha GN, KL Sehgal, E Mitra and AC Nandi 1971. Studies on the seasonal and diurnal variations in physico-chemical and biological conditions of a perennial freshwater pond. J. Inland Fish Soc. India 3: 97-102.

11. Singh RK, NP Shrivastava and VR Desai 1980. Seasonal and diurnal variations of physicochemical conditions of water and plankton in lotic secor of Rihand reservoir (Uttar Pradesh). J. Inland Fish. Soc. Ind. 12(1):100-111. 
12. Bhuiyan AS and Q Nessa 1996. Study on some physico-chemical parameters of a fish pond in Rajshahi. J. Bio-Sci. 4: 171-173.

13. Bhuiyan AS and Q Nessa 2000. Photic hours migration of some zooplankton in a fish pond in relation to physico-chemical parameters. Bangladesh J. Life Sci. 12(1\&2): 53-57.

14. Bhuiyan AS, Q Nahar and MN Islam 1997. Physico-chemical condition in relation to meteorological condition of a fish pond in Rajshahi. Univ. J. Zool. Rajshahi Univ. 16: 85-88.

15. Ward HB and Whipple GC 1959. Freshwater biology. (2 ${ }^{\text {nd }}$ ed.). John-Willy and Sons. Inc., New York.

16. Mellanby H 1962. Animal life in freshwater. (6th ed). Cox and Wyman Ltd. London.

17. Needham J G and Needham RP 1972. A guide to the study of freshwater biology. Holden-day, INC. Cali 94(III), U.S.A.

18. Tonapi GT 1980. Freshwater animals of India. Oxford and IBH Publishing Co., New Delhi110001.

19. Beeton AM 1960. The vertical movement of Mysis relicta in lakes Huron and Michigan. J. Fish. Res. Bd Canada 17: 517-539.

20. Hussain SV 1967. Studies on the limnology and primary production of a tropical lake in India, Hydrobiol. 30: 35-352.

21. Miah MJU and S Dewan 1977. Diet patterns of feeding of a major carp, L. rohita in a Bangladeshi pond. Bangladesh J. Agri. Sci. 4(1): 81-88.

22. Bhuiyan AS, SN Islam and SS Bhuiyan 2008. Seasonal occurrence of some copepods in relation to the physico-chemical condition of a fish pond in Rajshahi Bangladesh. Fishing Chimes, India 28(4) : 39-41.

23. Bhuiyan AS, MT Islam and R Sharmeen 2008. The occurrence and abundance of some copepods in a fish pond in Rajshahi, Bangladesh in relation to the physico-chemical conditions. J. Bio. Sci. 16: 115-119. 